\title{
POESIA E REAL: ESBOÇOS DA RÚSSIA ATUAL
}

\section{Aurora Fornoni Bernardini}

Vitali Makhlin, professor de filosofia da Universidade Estatal Pedagógica de Moscou escreveu recentemente um ensaio brilhante (publicado em 2010 pela Routledge, com o título de "Beyond the text", no volume Critical Theory in Russia and the West organizado por Alastair Renfrew e Galin Tihanov), onde faz um análise lúcida da Rússia atual, do ponto de vista do impasse sócio-histórico-filosófico em que se encontra o país e que, como ele aponta, vem de longe.

Como na Rússia "literaturocêntrica" os poetas — desde Púchkin e Lérmontov — sempre foram os mais agudos intérpretes do sentido que serpenteia por baixo do aparente — do " além do texto", como diz o autor —, vamos aqui colher alguns momentos da poesia russa contemporânea (que traduzi), para que toquem, com seus versos, necessariamente ambíguos, certas questões apontadas pelo filósofo, nessa fase de dispersão de identidade, não apenas russa, obviamente.

\section{Nesse mundo de fim dos paradigmas, em que cada um interpreta o que quer, há como distinguir o falso?}

\section{I - Jóssif Bródski (1940-1996)}

Я родился и вырос в балтийских болотах, подле серых цинковых волн, всегда набегавших по две, и отсюда - все рифмы, отсюда тот блеклый голос, вьющийся между ними, как мокрый волос, если вьется вообще. Облокотясь на локоть, раковина ушная в них различит не рокот, но хлопки полотна, ставень, ладоней, чайник, кипящий на керосинке, максимум - крики чаек. В этих плоских краях то и хранит от фальши сердце, что скрыться негде и видно дальше. Это только для звука пространство всегда помеха: глаз не посетует на недостаток эха.

Nasci e cresci nos pântanos do Báltico, lugares onde ondas cinza de zinco sempre correm aos pares; daí todas as rimas, daí a voz atenuada que entre elas se enrola, qual cabelo molhado; 
se é que se enrola. Mesmo o cotovelo fincado,

a concha do ouvido não distingue nelas nenhum chiado, apenas bater de telas, de postigos, de palmas, o apito

de chaleiras fervendo no fogão - no máximo - o grito

das gaivotas. Nesses países planos o que retém

do falso o coração, é que nada se esconde e vê-se além.

Apenas para o som o espaço é estorvo:

pela falta de eco não se queixa o olho.

\section{O passado não assimilado (não expiado) não permite a percepção do novo?}

\section{II - Gleb Chulpiákov (1971-)}

прозрачен как печатный лист, замысловат и неказист, живет пейзаж в моем окне, но то, что кажется вовне окна, живет внутри меня в саду белеет простыня, кипит похлебка на огне, который тоже есть во мне, и тридцать три окна в дому открыто на меня - во тьму души, где тот же сад, и в нем горит, горит сухим огнем, что было на моем веку (кукушка делает «ку-ку») и вырастает из огня пейзаж, в котором нет меня.

Transparente feito folha de sermão, Informe e complicada em minha mão, Vive a paisagem na janela, Mas aquilo que aparece fora dela Mora dentro de mim -

Branqueja no jardim a linha Do varal, ferve o caldo negro no fogão Que também pertence ao meu quinhão, E 33 janelas, eu asseguro,

Abertas para mim, no escuro

Da alma onde há o mesmo jardim

E nele referve a fogo frio sem fim $\mathrm{O}$ que se passou em meu espaço secular (E o cuco a cucuar) -

E do fogo cresce uma paisagem

Onde não existe a minha imagem. 


\section{É ele que se renova e volta a assombrar? (a mulher de avental branco)}

когда не останется больше причин, я выйду в сугробы ночного проспекта, где плавают голые рыбы витрин и спит молоко в треугольных пакетах в начале начал, где звенит чернозем, я буду из греков обратно в варяги и женщина в белом халате подъем сыграет на серой, как небо, бумаге.

quando já não houver motivo algum sairei p'ros montes de neve, para a rua, onde nadam nas vitrines os peixes nus e dorme o leite em caixas de três bicos e voltarei ao começo, onde crepita a terra e dos gregos aos variagues, em tropel, mas a mulher de avental branco apita e troa num cinza como o céu, canudo de papel.

Perdido o sentido de comunidade e de outridade, só restando a "diferença", em que qualquer discussão é impossível, o que resta? A conversação consigo próprio, com suas próprias bizarrices?

какой-нибудь полузабытый мотив на старом базаре, и сердце разбито, а в небе качается белый налив и тянется вдоль переулка ракита какой-нибудь малознакомый квартал, где снежную бабу катали из глины я знаю! там желудь за шкафом лежал, а мимо несли бельевые корзины, их ставили в небо одну за другой, и двигались простыни над головой

algum motivo meio esquecido num velho brechó e: o coração partido.

Mas no céu se agita uma luz esbranquiçada e o salgueiro arrasta suas ramas pela estrada. Algum bairro desconhecido e singelo onde fizeram de argila uma boneca de gelo. Eu sei! Lá estava a bolota atrás do armário, e carregavam perto as cestas dos sudários, puseram-nas no céu uma atrás da outra, e lá se vão os panos sobre a cabeça oca 


\section{Impera o sentido da finitude de tudo, a começar pela vida?}

гуди, гуди — мой черный ящик, на пленку сматывай, пока мой привередливый заказчик не обесточил провода пока потрескивает сверху его алмазная игла я не закрою эту дверку мне по душе его игра, в которой медленно и тускло, без препинания и шва, слова прокладывают русло реки наверх - а жизнь прошла.

zune, zune - minha caixinha preta, enrola-te no filme até o meu chefe careta não desligar a força, na mutreta, até a agulha diamantina continuar crepitando lá de cima não fecharei a portinhola eu adoro esta música onde confusa e embaçada descosturada e corrida escava a palavra o leito rio acima - e lá se foi a vida..

O que se sente ao passar da visão de antes — quase religiosa — de uma "ideologia científica", à total desintegração de qualquer discurso, "além do limite"?

\section{III — Vera Pávlova (1963-)}

\section{5}

Я уже совсем большая, мне уже совсем все можно: посещать любые фильмы, покупать любые вина и вступать в любые браки, и влезать в любые драки, и за все перед народом уголовно отвечать. Пожалейте меня, люди не управиться с правами! Пожалейте меня, люди запретите что-нибудь 
1985

Já estou bastante grande, já me tudo é permitido: ver os filmes que me agradam, comprar o melhor vinho, me meter em certa intriga e cair em qualquer briga. E por tudo, frente a todos, responder criminalmente. Tenha dó, ó minha gente Com direitos, quem aguenta? Tenha dó, ó minha gente, Proíba algo, urgentemente!

\section{E quanto ao círculo vicioso da própria consciência?}

1990

если есть чего желать значит будет о чем жалеть если есть о чем жалеть значит будет о чем вспомнить если есть о чем вспомнить значит не о чем было жалеть если не о чем было жалеть значит нечего было желать

1990

Se há o que desejar haverá o que lamentar se há o que lamentar haverá do que lembrar se há do que lembrar não havia o que lamentar se não havia o que lamentar nada havia a desejar

Alguns propõem reviver o passado. Pode ser a solução?

IV - Ossip Mandelstam (1891-1938)

Образ твой 
Образ твой, мучительный и зыбкий, Я не мог в тумане осязать.

"Господи!"- сказал я по ошибке,

Сам того не думая сказать.

Божье имя, как большая птица, Вылетело из моей груди!

Впереди густой туман клубится, И пустая клетка позади...

\section{Tua figura}

Tua figura confusa e sofredora

Não pude ver na névoa circundante.

"Deus !" - saiu-me a palavra enganadora,

Sem eu saber, apenas num rompante.

O nome Deus, feito uma ave imensa

Voou-me do peito em disparada!

À minha frente a névoa se condensa,

E atrás, a gaiola abandonada...

Chegou-se ao "fim da conversação": assiste-se ao passar de todas as tensões e fundações precedentes e relativamente persistentes, tanto sociais, quanto de qualquer natureza; chegou-se à "mentalidade do caos". E o amanhã?

\section{V - Tarassik Petrítchenka (1975-)}

$3 a$

За июль послушно бабочка порхает, Белой ночи растопырив пальцы.

Кто тебя сегодня угадает?

Кто заставит девочку смеяться?

Кто, как белый стих, спокойно лечит?

Кто целует родинки - запястья?

Кто целует ноги, губы, плечи?

Кто подарит клеточку на счастье?

Мы ли идиоты в самом деле?

Мы ли распинались в поцелуях?

И теперь всегда — «как мы посмели?»

Мимо тех, кто был «какого хуя?»

Завтра начинается на совесть.

Завтра, лучше б ты не начиналось.

«Кто есть?» или «Кто-нибудь!» и «То есть...» 
Завтра - это маленькая малость.

Сделай вид, что я не интересен, Все эти рассказы, пляски, песни... Мы ныряем в завтрашнюю плесень. Мы устали... Наливай по 200!

\section{Durante}

No mês de julho esvoaça a borboleta, À noite branca, os dedos despregados. Quem adivinha hoje a sua falseta? Quem leva a menina a dar risada?

Quem cura calmamente? O verso branco?

Quem beija as pintas do rosto? A cicatriz?

Quem beija os lábios, os pés, as mãos?

Quem dá uma gaiola, para ser feliz?

Somos idiotas, ou não percebe ?

De tantos beijos, não o crucificamos?

E agora dizemos - "como ousamos?"

Além daqueles que dizem "que cacete!"

O amanhã começa na consciência.

O amanhã, melhor não ter nenhum.

"Quem é?" ou " Isto é..." ou "Qualquer um!"

$\mathrm{O}$ amanhã - é uma coisinha à toa.

Faça de conta que não me interesso,

Todos os contos, as danças, as canções...

Mergulhamos no lodo do amanhã.

Já cansados... enche de vodka, numa boa! 